doi: 10.52370/TISC2162AZ

\title{
COVID-19 EFFECTS ON TOURISM SECTOR AND IMPLICATIONS FOR TOUR GUIDES PROFESSION IN SERBIA
}

\author{
Andrea Žerajić ${ }^{1}$
}

\begin{abstract}
The tourism industry is one of the sectors that have been hit the hardest by the Corona crisis worldwide. The pandemic has crippled domestic and international travel for the most part, resulting in significant revenue losses and liquidity problems for all tourism businesses. In the aftermath of the crisis, the industry will have to contend with people's increased need for security and trust. Tourism and hospitality industry are the most endangered industries across the globe. Tour guides represent the profession that may have been affected the most, precisely because of the seasonal nature of their work, as well as because of the way they are engaged. This paper aims to point out the problems faced by tour guides during the pandemic as well as to present, through interviews with tour guides in Serbia, the position and efforts of the professional association of tour guides of Serbia and their attempts to improve their status during this period.
\end{abstract}

Key Words: tourism and hospitality industry, tour guides, Covid-19, endangered industries

JEL classification: Z32

\section{Introduction}

Tourism is one of the most dynamic economic sectors in the world. It is also the fastest growing one. It can be said that it promotes job creation and local economic development, culture and products. The above is reflected in several of the Sustainable Development Goals (Sandvik, 2020). The COVID-19 pandemic has severely affected the tourism industry (Gössling et al., 2020; Hall et al., 2020). However, Mayer, Bichler \& Peters (2020)

\footnotetext{
${ }^{1}$ Andrea Žerajić, PhD, professor of vocational studies, Academy of Applied Studies Belgrade, Belgrade, 0631110777, andrea.zerajic@vhs.edu.rs
} 
point out that crises and catastrophes are nothing new when global tourism is in question. They listed a number of such crises (e.g. 9-11, tsunami in the Indian Ocean, SARS, global financial and economic crisis, etc.). Haggett (2000) emphasizes that disasters can be understood as unexpected, unavoidable events that produce effects on several levels, cause physical damage, social or long-term ecological changes. They have global effects over great distances and longer periods of time. However, crises "disrupt the proper functioning of the tourism industry" (Laws \& Prideaux, 2005, p. 2).

Tourism contributes both directly and indirectly to job creation. In 2019, this industry accounted (directly and indirectly) for approximately 330 million jobs worldwide, or $10.3 \%$ of total global employment, or equivalent to one in ten jobs worldwide (World Travel \& Tourism Council, 2019). For every job created directly in tourism, nearly one and a half additional jobs are created through indirect or induced effects. The labor-intensive accommodation and catering subsectors alone provide about $30 \%$ of all workers employed in establishments with 2 out of 9 employees.

Disastrous effects on the accommodation and food services sector can be seen throughout the world. They affected 144 million workers. This sector has suffered from the full closure in some countries to a steep decline in demand in these rare cases where operations can continue (International Labor Organization - ILO, 2020). If we take into account that most of these businesses are micro, small and medium-sized enterprises (MSMEs) with fewer than 50 employees (ILO, 2020), it is no wonder that the number given above includes around 44 million self-employed workers and 7 million employers.

This paper is specially dedicated to the profession of tour guides and their position during pandemic. Tour guides can be seen as extremely important for the industry. They possess the knowledge of a certain area, its potentials and challenges. They are in touch with the people. When developing a sustainable tour, social and ecological standards are not the only ones that matter. There are also needs of the local population. The tourism industry is extremely important for job creation, therefore the paper will encompass not only to the negative effects of COVID-19 on the employment, but also its impact on the travel and tourism sector in general and on the tour guide profession in Serbia in particular. 


\section{The impact of COVID-19 and containment measures on the travel and tourism sector}

The impact of COVID-19 on the tourism sector should be mitigated through early, broad and coordinated policy efforts and the establishment of appropriate mechanisms. Short, medium, and long-term policy solutions should be developed according to the International Labor Organization (ILO, 2020)'s Framework for Managing the COVID-19 Pandemic, based on the four interlinked pillars mentioned above:

- Business and employment incentives;

- Support for businesses, jobs and income;

- Protection of workers in the workplace;

- Finding solutions through social dialogue.

The tourism sector will not emerge from the COVID-19 crisis without an aftermath. However, it is known for its resilience to economic downturns and crises and could recover quickly. Therefore, once the crisis is over, it can play a central role in reviving the world economy. Improved "Build Back Better" in the post-pandemic era could bring the tourism industry closer to the Sustainable Development Goals and become a greener, more inclusive and resilient industry that provides decent work to all involved in tourism. The tourism industry, as a cross-sector industry, is being hit extremely hard by the current crisis in 2020 with the restrictions on travel and movement and the decline or lack of demand. In the meantime, the Corona regulations have been relaxed several times and the vitalization of tourism has fortunately started again in summer - nevertheless, there are still restrictions.

The European Commission (2020) has released the data about the Member States most dependent on tourism (\% of GDP): Croatia (25\%), Cyprus (22\%), Greece (21\%), Portugal (19\%), Austria, Estonia, Spain (15\%), Italy (13\%), Slovenia, Bulgaria (12\%), Malta (11\%), France (10\%), and Germany (9\%).

The tourism industry is facing a challenge that has never been seen before in many countries. Measures have been taken to retain customers and encourage future bookings. Some companies belonging to the tourism industry have adjusted their rules for canceling flights and hotel stays, but also for package tours. TUI has ceased all business operations. Customers can choose whether they want to cancel a booked trip and get the money back or book a new trip. Airlines have also relaxed their terms and 
conditions - Lufthansa reimburses the customer for the money, Ryanair has temporarily ceased operations, EasyJet is less accommodating and, despite global travel warnings, invokes the terms and conditions, which do not allow short-term cancellations. Customers can rebook their flight for a later date.

A number of measures have been taken to contain the virus which greatly affected travel and tourism sector, including travel restrictions and reduced opening times for restaurants.

Travel restrictions. - Many countries have issued entry bans. The Corona crisis in tourism has thus reached its peak. Travel will not be possible for the foreseeable future. Travel for tourist purposes is also prohibited within Germany and so are bookings of hotels and holiday apartments.

Reduced opening times for restaurants. - In many federal states, restaurants are only allowed to open until 6 p.m. This leads to considerable losses for the restaurant operator.

The gastronomy is also affected. Restaurants may only be open for a limited time. There are other rules as well: the tables must be set up at a distance of 1.5-2 meters from each other. This automatically limits the number of guests. In addition, more and more people adhere to the requirements. They avoid the public and only go out for necessary errands or to the doctor. The large population group of the elderly is required not to leave their home at all. These many restrictions are spurring the Corona crisis in tourism and the hotel industry. As a result, the income in many hotels and restaurants has collapsed completely.

But there is also a lack of income for other industries. Owners of holiday apartments, campsites and holiday complexes often used for accommodating students are also affected because of the lack of school trips. Due to the nationwide area-wide restrictions and the absence of foreign guests, it can be assumed that the forecast of sales losses will increase. Consequently, loss of income leads to staff being laid off in order to reduce costs.

\section{The impact of COVID-19 on employment in tourism}

The COVID-19 outbreak has had a devastating impact on the global economy and employment. Accommodation and food services have been 
identified by ILO (International Labor Organization) as a subsector of the economy that is extremely likely to witness a drastic fall in economic output because of the COVID-19 crisis. The sector is labor intensive and employs millions of poorly paid and low-skilled workers, the majority of whom are women. In many countries, those workers now face drastic and devastating reductions in their working hours, significant pay cuts and the potential loss of their employment. Almost all businesses in the accommodation and food services subsector, regardless of their size, are likely to struggle to stay afloat.

The tourism industry has been hit hard by the measures needed to contain the pandemic and it is unpredictable when the situation will be normalized. Even after the containment measures are gradually eased, surviving businesses will continue to face the challenges that are associated with what is likely to be a slow recovery. The ILO (2020) estimates that 305 million full-time equivalent jobs could be lost due to the pandemic, many of which in the tourism industry.

Because of the global efforts to contain the pandemic, the international tourism industry could shrink by 45 to $70 \%$. Currently this has affected the domestic tourism industry as well, as about half of the world's population is subject to restrictions associated with containment measures (Organization for Economic Co-operation and Development - OECD, 2020). According to the latest data from the World Tourism Organization, international tourism fell by $22 \%$ in the first quarter of 2020 and there was a decline of between $60 \%$ and $80 \%$ in 2020 compared to 2019. By March 2020 there were fewer tourists (67 million) compared to the previous year, which led to the loss of 80 billion USD (World Tourism Organization UNWTO, 2020). The decrease in international tourism could reach $70 \%$ if there is no recovery by September 2020, according to preliminary estimates by the Organization for Economic Co-operation and Development (OECD, 2020) on the impact of COVID-19 on tourism. In addition, domestic tourism has also been hit hard by measures to prevent the spread of the virus. However, a faster recovery is expected compared to international tourism, with the growing role of this branch of tourism during the recovery phase. Tourism represents a significant part of many national economies and directly accounts for an average of $4.4 \%$ of GDP and $6.9 \%$ of employment in OECD countries. These data are provided in the latest OECD Study on Tourism Policies. 
Hotels, restaurants, tour operators, airlines and cruise ships have suspended operations indefinitely. In the accommodation and food service subsectors, 51 million businesses must operate in an exceptionally difficult business environment, which has a significant impact on employment opportunities (ILO, 2020). In the face of the drastic economic downturn, workers in the labor-intensive tourism industry are now facing growing decent work challenges (ILO, 2020).

Another challenge for tourism is the high proportion of informal employment. This is because of the seasonality of the industry and inadequate regulation, enforcement and unionization (ILO, 2017).). The informal economy is strongly marked by deficits in decent work, such as excessive working hours, low wages, lack of social protection and gender discrimination. Informal or casual employment is more frequent among migrant workers, women, and the young.

According to the Statistical Office of the Republic of Serbia (2020), for example, in the fourth quarter of 2020, the number of the unemployed was 321,000 . The employment rate for the given period was $49.7 \%$. According to the Labor Force Survey for the fourth quarter of 2020, the employment rate remained unchanged, while the unemployment rate increased slightly, by $0.2 \% \%$ points (p.p.), compared to the fourth quarter of 2019. The yearon-year decrease in the number of employed amounts to 17,400, while the year-on-year increase in the number of unemployed amounts to 6,900. At the same time, the number of residents aged 15 and over decreased by 30,200 , and the inactive population decreased by 19,800 . According to the Labor Force Survey for the fourth quarter of 2020 and compared to the third quarter of the same year, the population aged 15 and over decreased in employment $(-15,700)$ and inactivity $(-20,900)$, while unemployment increased $(+29,000)$. At the inter-quarter level, employment and inactivity rates decreased by 0.2 p.p. and 0.3 p.p. respectively and reached the level of $49.7 \%$ and $44.9 \%$ in the fourth quarter of 2020 . At the same time, the unemployment rate rose by 0.9 p.p. and reached a level of $9.9 \%$.

Additional indicators, recommended by the European Statistical Organization - Eurostat, can better monitor trends in the labor market affected by the coronavirus pandemic. Additional indicators refer to total labor market slack, absence from work, work from home and hours worked.

The stagnation in the labor market in the fourth quarter of 2020 amounted to $19.0 \%$. It is 0.6 p.p. lower if compared to the same period in 2019 , while 
compared to the third quarter of 2020 it is higher by 0.3 p.p. It suggests there was an unsatisfied need for employment less than a year ago, i.e. before the crisis caused by the pandemic.

According to Falk \& Hagsten (2020), tourist destinations and companies are also affected at the regional and local level. On the one hand, the actual economic losses have arisen due to the absence of guests, with consequences for the economic structure or the financial situation of the tourist. Companies and possible government support measures have different individual consequences for companies and actors. On the other hand, there are certain negative image effects at the local/regional (possibly even national) level due to the increased spread of the COVID-19 virus through some tourist "superspreader" locations.

\section{Role of tour guides during Covid-19 pandemic}

Tourism is at the heart of a vast ecosystem of businesses that make a significant contribution to prosperity and employment in all states. At the same time, the tourism industry is the one that was hit the most last year by the Corona crisis worldwide, especially Europe as the most important tourist destination in the world. As a result of the COVID-19 pandemic, the tourism industry in the world is under unprecedented pressure. The pandemic has crippled domestic and international travel for the most part, resulting in significant revenue losses and liquidity problems for all tourism businesses.

In contrast to other industries, tourism is not only bearing the consequences of the COVID-19 pandemic but has also made a significant contribution to its rapid global spread. The effects of the extensive lock-down to contain the pandemic on tourism are massive on various scales. On a global level, intercontinental travel has largely come to a standstill with almost all countries in the world (96\%) issuing far-reaching entry restrictions. In contrast to previous crises in the last two decades (e.g. 9-11, SARS epidemic, global financial and economic crisis), COVID-19 has led to a break in the uninterrupted growth trend in global tourism since the end of the Second World War. At the national level, travel restrictions in the wake of the COVID-19 pandemic are particularly affecting economies that are heavily dependent on tourism.

The challenges facing tourism were already enormous in the run-up to the Corona crisis. The travel industry suffered from a loss of confidence and 
image that began with insolvencies and was further fed by geopolitical uncertainties. In addition, the debate about climate impacts and overtourism had significantly changed individual travel behavior. Due to the increasing merging of "work" and "life" and trend phenomena such as "workation", business travel was also undergoing major changes. For some time now, the tourism industry has fluctuated between seemingly unchecked growth and a plethora of fundamental challenges that make a profound rethinking and reorientation indispensable in the long term.

COVID-19 causes also many problems in the labor market. Jobs, including the catering, event and travel industries, are under pressure, and companies are reluctant to recruit new employees. Understandable, but unfortunately this also means that it is often more difficult for (beginner) job seekers to find a job.

Again and again we read that many people are afraid of losing their job due to the Corona crisis. This is because older workers often have permanent contracts, and this makes it easier for companies to terminate young workers' contracts. However, COVID-19 is also an obstacle for job seekers. While companies often made too high demands in the past, the number of jobs has also decreased significantly in recent times. It is a difficult time for ambitious beginners who want to put their knowledge into practice.

With the appearance and spread of the Corona virus in the world, tourist trips were canceled, which drastically affected the work of tourist guides. At this moment, it is clear that the tourism sector in Serbia is experiencing a complete catastrophe and that the recovery of this sector is extremely uncertain.

The travel year 2020 was a catastrophic one. There was the decline of $74 \%$ in global tourism worldwide. According to the latest survey by the UN tourism organization UNWTO, the situation is linked to over a hundred million jobs. In view of the travel restrictions, the forecasts for 2021 remain cautious. A trend is emerging on vacation at home, nature vacation and more interest in sustainable travel.

In her empirical research, Breede (2008) states that tourism and the intercultural encounters that go with it promote mutual understanding and the reduction of prejudices and xenophobia. According to Breede (2008), the tour guides make an important contribution to mediation in this context. They have an enormous amount of experience with regard to intercultural 
encounters, which results from their everyday work. Tour guides have the opportunity to establish contacts between the local population and the travelers (p. 310). In her remarks, Breede (2008) puts the function of tour guides for travelers in the foreground. Knowledge and experience of the tour guides can also be very interesting and useful for the society. Intercultural encounters in tourism can actually have positive socio-cultural effects on the society of the destination country. The experience of the tour guides can be stored and accessed by the future travelers. According to Žerajić (2019) tour guides can mediate between groups and people from different cultural systems and are thus able to reduce prejudices, reduce conflicts and initiate a change in thinking. They are also involved in intercultural encounters, for example in restaurants, in accommodation, shopping or on the road, in public transport. They can organize arranged meetings as part of sightseeing or directly in the form of an exchange dinner.

According to Žerajić (2020), the knowledge about the origin and development of traveling in its historical dimension qualifies a tour guide to assess the importance of this aspect of quality of life correctly, which has become immensely important in our society.

For intercultural communication, according to Cohen (1985) tour guides in particular play an important role in their function as interpreter tour guides. They take on an important role as an intermediary between travelers and locals. Most of the tour guides speak the language of the destination country as well as that of the source country of the tourists. They act as relationship catalysts between visitors and locals. According to Nettekoven (1979), they enable communication, understanding and interaction between people who speak different languages and belong to different cultures. In this context, however, their value surpasses that of the mere translator. As Wyatt points out (1978/79), they in fact communicate much more effectively and transfer knowledge and skills from one culture to another (Wyatt, 1978/79). According to Gentemann \& Whitehead (1983), they take the values, codes and symbols of one culture and transfer them to the other culture. In addition, tour guides can specifically promote communication between travelers and visitors by promoting and organizing encounters and communication.

It turns out that the negative consequences for the economy can be enormous. The Corona crisis hits tourism and the hotel industry particularly hard. People are urged to stay home and refrain from traveling. The extent 
of the consequences of this crisis cannot be foreseen today and one of the most affected professions is definitely the tour guide.

In order to get first-hand information about all the activities of the Association of Tourist Guides of Serbia as the oldest professional association that brings together licensed tourist guides since 1966, interviews were conducted with their members of the board ${ }^{2}$. Thus, the next steps were taken during the pandemic period, with the aim of ensuring the minimum wage to its members. Considering that the activity of tourist guides is very specific, an appeal was sent to the highest state institutions for help to the tourism industry and public transport in road traffic. Serbian tour guides have sent an open letter to the Government and warned that during the Corona virus pandemic they were neglected and completely without income. Those engaged in temporary and occasional jobs or by work or copyright contracts, are deprived from receiving state aid. On that occasion, the guides pointed out that for a number of years they had contributed to making the stays of statesmen, delegations, businessmen, experts and other high-ranking guests in the Republic of Serbia as pleasant as possible and that they are now facing a complete catastrophe in Serbia. The recovery of this sector is extremely uncertain. In 2020 the pandemic occurred at the beginning of the tourist season and thus left them without any income at a time when they were already running out of funds, eagerly awaiting the start of the new season.

Unlike caterers, hoteliers and carriers, they actually work only during the tourist season. As the law on tourism allows more ways of hiring tourist guides, it further complicates their situation.

The tour guides were left without markets, guests and business opportunities at the very beginning of the season last year. Therefore, most of them have unfortunately come to a situation where they cannot meet their obligations to the state in terms of pension and health insurance. Their daily existence is also endangered. Thus, tourist guides, who contribute to a positive image of our country in the world with their work and commitment, were forced to seek help in all instances of the state in the previous months. They turned to the whole sector for help and asked for:

1. Payment of gross minimum for a period of 6 months;

2. Write-off of tax liabilities and for the first three months of general economic assistance;

${ }^{2}$ All the information is obtained from this body directly. 
3. Moratorium on liabilities to financial institutions for the next 9 months;

4. Additional funds for the tourism and transport sector in the Development Fund of the Republic of Serbia with an accelerated procedure for approving and disbursing loans;

5. Postponement of obligations to pay property tax and profit tax for the duration of extraordinary circumstances.

Despite all the difficulties in the previous period and at present, the association of tourist guides of Serbia is trying to resist everything that the profession is facing and continuously working on training in the form of organizing online annual professional seminars in the country and abroad. In addition, the motivation of the guides during the pandemic was shown in the fact that they did not give up on regular activities such as marking the World Tourist Day in the form of walking tours in Belgrade. Each type of professional training implied the voluntary appearance of members of the association who, although left without income and engagement for months, gladly responded to the invitation to give a lecture to other colleagues or bring interested people on walking tours.

In cooperation and under the auspices of Tourist Association of Serbia, The Association of Tour Guides of Serbia organized at the beginning of this year an online conference on the actual and very popular topic Tourism after Covid 19 - Tourist guide in the period after the pandemic, what to expect and how to prepare on the following topics:

1. Work with domestic individual tourists

2. Work with foreign individual tourists

3. Work with VIP clients

4. Tourists with special needs

5. Work with groups in the country and abroad:

5.1. Domestic

a) children

b) pupils and students

c) adults

5.2. Foreign (bus circular tours, air, cruises, cycling, mountaineering,...)

6. Activities:

6.1. Outdoors

a) in the city during a walking tour

b) at archeological sites and open-air museums

c) in nature parks

6.2 Indoors

a) in transport 
b) in museums and galleries

c) in hotel and catering facilities

d) in halls (during the program - congress ceremonies... etc.)

7. Insurance (types and methods of policy activation)

8. Health services

In July 2020, the Protocol on Cooperation between UTVS and the Association of Tourist Guides of Novi Sad and the Association of Tourist Guides of Niš was concluded, signed and certified. This has enabled the Association to represent the interests of the associations in Novi Sad and Niš before state bodies in order to provide assistance and support. Based on the Rulebook for employers and employees with preventive measures to prevent the spread of the coronavirus epidemic (Official Gazette of RS, 94/2020), adopted by the Ministry of Labor in July 2020, the Association adopted a plan for implementing measures in accordance with the rulebook and posted all necessary information at the entrance to the Association of Tour Guides of Serbia.

At the invitation of YUTA, the Association took part in a joint appeal for help for the entire tourism sector.

Towards the end of 2020, the Association became a member of the European Federation of Tourist Guides Associations (EFTGA) and participated in a survey on the impact of Covid-19 on tourist guides, which all EFTGA tour guide associations should forward to its members. Based on the results of the survey, the EFTGA will make a report for all EFTGA member countries, which will be useful for us in future activities. They designed and organized an open-air press conference, called it the Public Hour, and after the first time it was clear that it would be a platform for increasing media visibility, presentation of activities and tasks of guides, and above all an opportunity for guides to acquaint the public with an extremely difficult situation.

During the Public Hour, they showed how they train young colleagues, pointed out the importance of the correct presentation of history, the destiny of a nation and its country, and took a look "behind the scenes" - at how safe transport of guests in Belgrade takes place and is organized. Public lessons were used as an opportunity to point out the plight of guides who lost their jobs due to the global pandemic caused by the Covid-19 virus. The media were present during public lessons. Print and digital media as well as the television broadcast interviews, statements and articles. 


\section{Conclusion}

As a result of the COVID 19 pandemic, the tourism industry is under unprecedented pressure. The pandemic has crippled domestic and international travel for the most part, resulting in significant revenue losses and liquidity problems for all tourism businesses. At the moment, both travelers and businesses are facing great uncertainty. In the aftermath of the crisis, the industry will have to contend with people's increased need for security and trust. It does not matter whether it is a vacation or a business trip: The future of tourism is becoming a question of quality, and the parameters will be different.

The reset brought about by the Corona crisis forced this rethinking at a stroke - and at the same time paved the way for a new reception of tourism. As painful as the pandemic is for the industry economically, it can - and must - be seen as the beginning of a new, more sustainable era for tourism, both globally and locally.

For the tourism industry, this presents an opportunity - and at the same time a challenge - to restore the relationship of trust with travelers. Because in the future, the choice of destinations and means of transport will increasingly depend on the guarantees and securities that tourism providers can provide. Guests crowded in hotels, deaths on cruise ships and guests stranded abroad have left their mark not only on those directly affected. Against this background, regional tourism will initially gain in attractiveness: short distances and local recreation convey a sense of security - just as familiar cultural circles promise emotional security. But supraregional destinations can also benefit if they can guarantee high standards, such as reliable conditions in terms of healthcare and transportation.

The theses on resonance and transformation tourism put forward by the Zukunftsinstitut in its trend study "Resonance Tourism" published at the end of 2019, will become a broadly effective reality after the crisis, transforming the tourism markets. The fundamental principle of resonance, the desire for sustainable relational experiences, will gain enormous momentum and strength from the experiences that each individual had in the context of the crisis. Post-Corona tourism will be a relationship and development tourism. 
According to the requests of the tour guides in Serbia, it can be concluded that few steps have been made. At the session of the Government of the Republic of Serbia in February 2021, the third package of economic measures to help citizens and the economy, worth 249 billion dinars, was adopted. The new set of measures will include direct assistance to entrepreneurs, micro, small, medium and large companies, support to the catering sector, hotels, travel agencies, the passenger and road transport sector, as well as one-time financial assistance to citizens and extension of the guarantee scheme to maintain private liquidity. In addition to one and a half minimum wages, support of a minimum wage will be provided to caterers, travel agencies, licensed tourist guides and companions, hotels, resorts and car rental agencies. The sector of passenger and road transport and bus stations will also receive the direct support.

Due to the global corona pandemic, travel is restricted in many countries. Even when tourism supply chains start functioning again, the recovery on the demand side will take some time, given the interconnectedness of the consequences of the economic and health crisis and the progressive lifting of travel restrictions. This will have major consequences for many national economies, particularly because of the significant share of tourism in many of them. This crisis will not last forever and we are optimistic that it will be possible to discover the world again in 2021 .

\section{References}

1. Breede, M. (2008). Interkulturelle Begegnung im alternativen Tourismus, Verlag Dr. Kovač, Hamburg.

2. Cohen, E. (1985). The tourist guist. The Origins, Structure and Dynamics of a Role. Annals of Tourism Research, Vol. 12, No. 1, 5-29.

3. European Commission, (2020), The EU helps reboot tourism, https://ec.europa.eu/info/live-work-travel-eu/coronavirus-response/travelduring-coronavirus-pandemic/eu-helps-reboot-europes-tourism_en, March 2021)

4. Falk, M. T., Hagsten, E. (2020). The unwanted free rider: Covid-19. Current Issues in Tourism, 1-6, https://doi.org/10.1080/13683500. 2020.1769575 . 
5. Gentemann, K.M., Whitehead, T. (1983). The Cultural Broker Concept in Bicultural Education. Journal of Negro Education, Vol. 52, No. 2, 118129.

6. Gössling, S., Scott, D., Hall, C. M. (2021). Pandemics, tourism and global change: A rapid assessment of COVID-19. Journal of Sustainable Tourism, Vol. 29, No. 1, 1-20.

7. Haggett, P. (2000). Geographie - eine globale Synthese, UTB, Stuttgart.

8. Hall, C. M., Scott, D., Gössling, S. (2020). Pandemics, transformations and tourism: be careful what you wish for. Tourism Geographies, Vol. 20, No. 3, 577-598.

9. International Labour Organization - ILO, (2017), ILO guidelines on decent work and socially responsible tourism, https://www.ilo.org/ wcmsp5/groups/public/---ed_dialogue/---sector/documents/normative instrument/wcms_546337.pdf, (28 March 2021).

10. International Labour Organization - ILO, (2020), ILO Monitor: COVID-19 and the world of work. $2^{\text {nd }}$ Edition, https://www.ilo.org/ wcmsp5/groups/public/---dgreports/---dcomm/documents/briefingnote/ wcms_740877.pdf, (28 March 2021).

11. Laws, E. Prideaux, B. (Eds.) (2005). Tourism crises: Management responses and theoretical insight, Routeledge, London/New York.

12. Mayer, M. Bichler, B. Peters, M. (2020). Covid-19 und Tourismus: Ein Mehrebenen-Überblick, COVID-19 als Zäsur? Geographische Perspektiven auf Räume, Gesellschaften und Technologien in der Pandemie, Heidelberg.

13. Nettekoven. L. (1979). Mechanisms of Intercultural Interaction. In E. de Kadt, (Ed.), Tourism: Passport to Development? (pp. 135- 145). Oxford University Press, New York.

14. Organisation for Economic Co-operation and Development - OECD, (2020), Tourism Policy Responsesto the coronavirus (COVID-19), https://read.oecd-ilibrary.org/view/?ref=124_124984-

7uf8nm95se\&title=Covid19_Tourism_Policy_Responses, (15 December 2020). 
15. Rulebook on preventive measures for safe and healthy work to prevent the occurrence and spread of epidemics of infectious diseases, Official Gazette of RS, 94/2020.

16. Sandvik, (2020), Annual report 2020, https://www.annualreport. sandvik/en/, (18 April 2021).

17. Statistical Office of the Republic of Serbia, (2020). https://www.stat.gov.rs/sr-latn/oblasti/trziste-rada/, (28 March 2021).

18. World Tourism Organization - UNWTO, (2020), International tourist numbers could fall $60-80 \%$ in 2020, UNWTO reports, https://www.unwto.org/news/covid-19-international-tourist-numberscould-fall-60-80-in-2020, (15 December 2020).

19. World Travel \& Tourism Council, (2019), Travel \& Tourism. Economic Impact 2019 World. https://www.slovenia.info/uploads/ dokumenti/raziskave/raziskave/world2019.pdf, (8 April 2021).

20. Wyatt, J. D. (1978/79). Native involvement in curriculum development: The native teacher as cultural broker. Interchange: A Journal of Educational Studies, Vol. 9, No. 1, 17-28.

21. Žerajić, A. (2019). Intercultural management and the importance of foreign languages in modern hotel industry. TISC - Tourism International Scientific Conference, Vrnjačka Banja, 4(1), 360-377.

22. Žerajić, A. (2020). Multilingualism in tourism. TISC - Tourism International Scientific Conference, Vrnjačka Banja, 5(1), 518-535. 